\title{
Opioid peptides encrypted in intact milk protein sequences
}

\author{
Hans Meisel ${ }^{1} *$ and R. J. FitzGerald ${ }^{2}$ \\ ${ }^{1}$ Bundesanstalt für Milchforschung, Institut für Chemie und Physik, Kiel, Germany \\ ${ }^{2}$ Life Science Department, University of Limerick, Limerick, Ireland
}

\begin{abstract}
Opioid agonistic and antagonistic peptides which are inactive within the sequence of the precursor milk proteins can be released and thus activated by enzymatic proteolysis, for example during gastrointestinal digestion or during food processing. Activated opioid peptides are potential modulators of various regulatory processes in the body. Opioid peptides can interact with subepithelial opioid receptors or specific luminal binding sites in the intestinal tract. Furthermore, they may be absorbed and then reach endogenous opioid receptors.
\end{abstract}

Opioid peptides: Milk protein

\section{Introduction}

Milk proteins are potential sources of opioid agonistic and antagonistic peptides. The structures of biologically active sequences were obtained from in vitro enzymatic and/or by in vivo gastrointestinal digests of the appropriate precursor proteins; chemical synthesis has been carried out to confirm the sequence of potential bioactive peptides (for reviews, see Teschemacher et al. 1990, 1994, 1997; Meisel, 1997a).

\section{General structural features}

Opioid peptides, i.e. opioid receptor ligands with agonistic activity, originate from different milk proteins and exert naloxone-inhibitable opioid activities in both receptor studies and during bioassays (Brantl et al. 1981). Milkprotein derived opioid peptides have been designated as 'atypical' opioid peptides (Teschemacher et al. 1994). These opioid peptides have N-terminal sequences different from that of the 'typical' endogenous opioid peptides, e.g. enkephalins, endorphins and dynorphins. 'Typical' opioid peptides are derived from three precursor molecules, proenkephalin, prodynorphin and proopiomelanocortin (Höllt, 1983). The common structural feature among endogenous and exogenous opioid peptides is the presence of a tyrosine residue at the amino terminal end (except $\alpha$ casein opioids) and the presence of another aromatic residue, e.g. phenylalanine or tyrosine, in the third or fourth position (Table 1). This is an important structural motif which fits into the binding site of opioid receptors. The negative potential, localized in the vicinity of the phenolic hydroxyl group of tyrosine, seems to be essential for opioid activity. Removal of the tyrosine residue results in a total absence of bioactivity (Chang et al. 1981). The proline residue in the second position $\left(\mathrm{Pro}^{2}\right)$ is crucial for the biological activity of opioid peptides because it is reported to maintain the proper orientation of the Tyr and Phe side chains (Mierke et al. 1990).

Opioid antagonists are peptides related to 'atypical' opioid peptides, i.e. they are opioid receptor ligands sharing several characteristics with agonistic opioid peptides derived from milk proteins (Teschemacher et al. 1994). They are not found in the sequence of endogenous precursors and their N-terminal amino acid sequence is not identical with that of the 'typical' opioid peptides.

\section{Occurrence in the sequence of milk proteins}

The major exogenous opioid peptides, i.e. $\beta$-casomorphins, are fragments of the $\beta$-casein sequence 60-70 (Tyr-ProPhe-Pro-Gly-Pro-Ile-Pro-Asn-Ser-Leu) (Table 1) and have been characterized as $\mu$-type ligands (Teschemacher et al. 1994, 1997). $\beta$-Casomorphins were found in analogous positions in sheep, water buffalo and human $\beta$-casein (for review, see Fiat \& Jollès, 1989; Teschemacher et al. 1990; Meisel \& Schlimme, 1996; Meisel, 1997a,b). An analogue isolated from a commercial hydrolysate of bovine casein, $\beta$-casomorphin-4-amide, designated as morphiceptin, is a highly potent $\mu$-selective opioid peptide (Chang et al. 1981). Three $\alpha$-casein-derived exorphins corresponding to bovine $\alpha_{\mathrm{S1}}$-casein peptide fragments 90-96 (Arg-Tyr-LeuGly-Tyr-Leu-Glu), 90-95 and 91-96 are $\delta$-selective receptor ligands (Loukas et al. 1983, 1990; PihlantoLeppälä et al. 1994). Whey protein-derived peptides which behave as $\mu$-opioid receptor agonists with low potency are the $\alpha$-lactorphin (Tyr-Gly-Leu-Phe) and $\beta$-lactorphin (TyrLeu-Leu-Phe) corresponding to residues $50-53$ in both bovine and human $\alpha$-lactalbumin and 102-105 in bovine $\beta$-lactoglobulin, respectively (Chiba \& Yoshikawa, 1986; Antila et al. 1991). Another whey protein-derived opioid

\footnotetext{
* Corresponding author: H. Meisel, phone +49 431609 2260, fax + 49431609 2300, email meisel@bafm.de
} 
Table 1. Examples of opioid peptides derived from bovine milk proteins (adapted from Meisel \& Bockelmann, 1999 and Antila et al. 1991)

\begin{tabular}{|c|c|c|c|c|}
\hline Bioactive peptide & Sequence $^{*}$ & $\begin{array}{l}\text { Precursor protein } \\
\text { (fragment) }\end{array}$ & $\begin{array}{c}\mathrm{IC}_{50}^{\dagger} \\
(\mu \mathrm{mol} / \mathrm{l})\end{array}$ & $\begin{array}{l}\text { Theoretical yield of } \\
\text { bioactive peptide obtainable } \\
\text { from } 1 \mathrm{~g} \text { precursor protein }(\mathrm{mg})\end{array}$ \\
\hline \multicolumn{5}{|l|}{ Opioid agonists } \\
\hline$\beta$-Casomorphin-7 & YPFPGPI & $\beta$-Casein (f60-66) & 14.0 & 33.0 \\
\hline$\beta$-Casomorphin-5 & YPFPG & $\beta$-Casein (f60-64) & 1.1 & 24.2 \\
\hline$\alpha_{s 1}$-Casein-exorphin & RYLGYLE & $\alpha_{s 1}$-Casein (f90-96) & 1.2 & 38.7 \\
\hline$\alpha$-Lactorphin & YGLF & $\alpha$-Lactalbumin (f50-53) & 67.0 & 35.2 \\
\hline$\beta$-Lactorphin & YLLF & $\beta$-Lactoglobulin (f102-105) & 38.0 & 30.2 \\
\hline Serorphin & YGFNA & Serum albumin (f399-404) & 85.0 & 10.5 \\
\hline \multicolumn{5}{|l|}{ Opioid antagonists } \\
\hline Casoxin A & YPSYGLNY & к-Casein (f35-42) & 400.0 & 51.4 \\
\hline Casoxin B & YPYY & $\kappa$-Casein (f58-61) & & 31.8 \\
\hline Casoxin C & YIPIQYVLSR & $\kappa$-Casein (f25-34) & 50.0 & 65.8 \\
\hline
\end{tabular}

* The one-letter amino acid code is used.

† Peptide concentration required to inhibit ${ }^{3} \mathrm{H}$-ligand binding by $50 \%$.

peptide, serorphin (Tyr-Gly-Phe-Asn-Ala), was isolated from fragment 399-404 of serum albumin (Tani et al. 1994).

Opioid antagonists have been found in bovine and human $\kappa$-casein (casoxins) and in $\alpha_{\mathrm{S} 1}$-casein (Chiba et al. 1989; Yoshikawa et al. 1994). Various synthetic casoxins were isolated as C-terminally methoxylated peptides, e.g. the derivatives corresponding to $\mathrm{K}$-casein sequences $33-38$ (Ser-Arg-Tyr-Pro-Ser-Tyr $\mathrm{OCH}_{3}$ ), 34-38 and 35-38 (Chiba \& Yoshikawa, 1986). The chemically modified casoxins were more active than the non-methoxylated fragments. The tryptic fragment corresponding to residues 25-34 (Tyr-Ile-Pro-Ile-Gln-Tyr-Val-Leu-Ser-Arg) of bovine $\kappa$-casein, known as casoxin $\mathrm{C}$, showed a relatively high opioid antagonistic activity in comparison to the esterified peptides (Chiba et al. 1989). Casoxins are opioid receptor ligands of the $\mu$-type with relatively low antagonistic potency as compared with naloxone. They also bind to $\kappa$-receptors where extension of the N-terminal amino acid sequence beyond the tyrosine residue seems to influence binding to $\kappa$-type receptors. Opioid antagonists were also found in human lactoferrin (Yoshikawa et al. 1988). These peptides, named lactoferricin A (fragment 339-344), B (fragment 544-548) and C (fragment 681687), behaved quite similarly to casoxins, i.e. C-terminally methoxylated $\mu$-opioid receptor-selective antagonists with moderate potency (Teschemacher et al. 1997).

\section{Functional significance}

Mammalian opioidergic systems consist of opioid receptors and their endogenous ligands, the opioid peptides. Depending on their location, their physiological significance appears to be related to a considerable number of neuroendocrine regulatory functions. Opioid receptors $(\mu-$, $\delta$ - and $\kappa$-type) are located in the nervous, endocrine and immune systems as well as in the intestinal tract of the mammalian organism and can interact with their endogenous ligands as well as with exogenous opioids and opioid antagonists (Teschemacher et al. 1994). Thus, opioidergic systems are open to all kinds of interferences from exogeneous opioids or opioid antagonists (Teschemacher et al. 1994). Modulation of social behaviour (Panksepp et al. 1984; Paroli, 1988) and analgesic effects (Chang et al.
1982; Matthies et al. 1984) were observed following intracerebral administration of opioid peptides with agonistic activity, e.g. $\beta$-casomorphins, to experimental animals. Orally administered milk protein-derived opioid peptides have been demonstrated to influence postprandial metabolism by stimulating secretion of insulin and somatostatin (Schusdziarra et al. 1983a,b), to modulate intestinal transport of amino acids (Brandsch et al. 1994), to prolong gastrointestinal transit time and to exert antidiarrhoeal action (Daniel et al. 1990a,b). Evidence has accumulated that the enhancement of net water and electrolyte absorption by $\beta$-casomorphins in the small and large intestine is a major component of their antidiarrhoeal action, which could be mediated via subepithelial opioid receptors or through specific luminal binding sites at the brush border membrane (Tomé et al. 1987; Brandsch et al. 1994). $\beta$-Casomorphins may also affect the human mucosal immune system, possibly via opiate receptors in lamina propria lymphocytes (Elitsur \& Luk, 1991).

The presence of opioid peptides in a living system or, at least, of the precursors from which these peptides could be liberated, is a prerequisite for any functional role in the system. It can be shown that relatively high amounts of bioactive peptides could potentially be produced during the ingestion of $1 \mathrm{~g}$ of each of the major casein and whey protein components (Table 1). Many opioid peptides are biologically very potent. Therefore, even nutritionally insignificant amounts of liberated peptides might be sufficient to exert physiological effects. These peptides may enter peripheral blood intact and exert systemic effects or they may produce local effects in the gastrointestinal tract. Results indicating the liberation of $\beta$-casomorphins from $\beta$-casein under in vivo conditions have been obtained from several studies. Evidence for the liberation of $\beta$ casomorphins from $\beta$-casein into the gastrointestinal lumen of mammals after milk intake has also been obtained. Peptides were found in the small intestinal contents of adult humans following cows' milk intake, which were identified by radioimmunological and chromatographical methods as $\beta$-casomorphins (Svedberg et al. 1985). Moreover, $\beta$ casomorphin-11 has been identified and chemically characterized in the duodenal chyme of Göttingen minipigs after feeding with bovine casein (Meisel, 1986). $\beta$ Casomorphins are claimed to be rapidly degraded once 
they enter the bloodstream. However, the presence of $\beta$ casomorphin-7 immunoreactive material has been demonstrated in the plasma of newborn calves following their first milk intake (Umbach et al. 1985). This material revealed a similar molar mass as $\beta$-casomorphin-11 and thus has been considered as a $\beta$-casomorphin precursor. Such precasomorphins could reach any potential site of action in the system to elicit physiological effects following liberation of the protected active sequence from the precursor molecule. Opioid casein fragments have not been detected in the plasma of adult mammals (Umbach et al. 1985; Teschemacher et al. 1986). Thus, only the neonatal intestine appears to be permeable to (pre-)casomorphins; in adult systems, the intestinal brush border membrane seems to be the main target site for the physiological effects of food-derived opioid peptides.

In addition to the possible liberation of bioactive peptides during intestinal proteolysis, such peptides may already be generated during manufacture of several milk products and thus be ingested as food components. For example, partially hydrolysed milk proteins for hypoallergenic infant formulas and for clinical applications in enteral nutrition consist exclusively of peptides. Furthermore, it has been demonstrated that a number of caseolytic bacterial species used in the production of some types of cheese and other milk products can produce casomorphins (Hamel et al. 1985). Several opioid peptides derived from $\alpha_{\mathrm{S} 1^{-}}, \beta$-casein and $\alpha$-lactalbumin were released by pepsin/trypsin hydrolysis of Lactobacillus $G G$ fermented UHT milk (Rokka et al. 1997). It has been found that the extracellular $\mathrm{P}_{\mathrm{I}}$-type proteinase of Lactococcus lactis hydrolyses more than 40 $\%$ of the peptide bonds of $\beta$-casein resulting in the formation of more than 100 different oligopeptides including a fragment of the $\beta$-casein sequence 60-68 which is part of $\beta$-casomorphin-11 (Juillard et al. 1995). Data obtained from 'non-starter' lactic acid bacteria (Lactobacillus ssp.) present in fermented milk products and in the human intestine indicate that their proteolytic system is comparable to Lactococcus lactis. No data are available on the action of the proteolytic enzymes from lactic acid bacteria in the human gut after ingestion of fermented milk products.

Irrespective of the potential function of milk-derived opioids as exogenous regulators, it is also possible that certain peptides from milk may directly influence the mother. For example, casomorphins can be liberated in the mammary gland, transferred to the blood and then reach endogenous opioid receptors (Teschemacher \& Koch, 1990). In this way, casomorphins may participate in the endocrinic regulation of pregnancy, e.g. by stimulation of prolactin release (Yen et al. 1985). The cardiovascular system in pregnant or lactating mammals may also be a target for casomorphin action. These peptides can exert a positive inotropic and antiarrhythmic effect and thus may have a cardioprotective function (Mentz et al. 1990; Teschemacher \& Koch, 1990). The physiological significance of these effects is as yet not clear.

\section{Dietary and pharmaceutical applications}

$\beta$-Casomorphins have been produced by genetic engineering techniques followed by enzymatic or chemical cleavage of the microbial fusion protein to liberate the required peptide (Carnie et al. 1989). These recombinant $\beta$-casomorphins are intended for oral administration in order to increase animal performance, e.g. weight gain or milk yield. As yet, no meaningful application in human nutrition has been described.

Several attempts were made to synthesize modified $\beta$ casomorphin sequences in order to find pharmacologically active peptides with higher analgesic potency, altered sideeffects and longer duration of action. A considerable increase in analgesic or antidiarrhoeal activity in dogs was obtained by substitution of L- with D-amino acids, e.g. Pro ${ }^{2}$ and $\mathrm{Pro}^{4}$, and by C-terminal amidation (Matthies et al. 1984; Daniel et al. 1990b; Mansfeld et al. 1990; Erll et al. 1994). Examples of chemically modified potent opioid peptides include morphiceptin ( $\beta$-casomorphin-4-amide) and casokefamide (D-Ala ${ }^{2,4}, \mathrm{Tyr}^{5}-\beta$-casomorphin-5-amide). Modifications to the natural casomorphins do not only influence the affinity of the resulting analogues for opioid receptors, but also alter their pharmacokinetics, particularly their inactivation by proteolytic/peptideolytic enzymes: substituted $\beta$-casomorphins have been shown to be more resistant to enzymatic attack and exhibit higher opioid potency than the natural peptides (Tomé et al. 1987; Daniel et al. 1990b).

\section{Conclusions}

The bioactivities of opioid peptides encrypted in major milk proteins are latent until released and activated by enzymatic proteolysis, e.g. during gastrointestinal digestion or food processing. It is evident from many studies that opioid peptide fragments originating from milk proteins are potential regulatory compounds and modulators of various regulatory processes in the body. Nevertheless, more research is needed to fully understand the physiological significance of milk-protein derived opioid peptides. $\beta$ Casomorphins and chemically modified analogues have already been considered for interesting applications as supplements for animal feed and as pharmaceutical preparations.

\section{References}

Antila P, Paakkari I, Järvinen A, Mattila MJ, Laukkanen M, Pihlanto-Leppälä A, Mäntsälä P \& Hellman J (1991) Opioid peptides derived from in-vitro proteolysis of bovine whey proteins. International Dairy Journal 1, 215-229.

Brandsch M, Brust P, Neubert K \& Ermisch A (1994) BCasomorphins - chemical signals of intestinal transport systems. In $\beta$-Casomorphins and Related Peptides: Recent Developments, pp. 207-219 [V Brantl and H Teschemacher, editors]. Weinheim: VCH.

Brantl V, Teschemacher H, Bläsig J, Henschen A \& Lottspeich F (1981) Opioid activities of $\beta$-casomorphins. Life Sciences 28, 1903-1909.

Carnie J, Minter S, Oliver S, Perra F \& Metzlaff M (1989) Nutritional compositions containing $\beta$-casomorphins. $U K$ Patent Application GB 2214810 A

Chang KJ, Cuatrecasas JP, Wei ET \& Chang JK (1982) Analgesic activity of intracerebroventricular administration of morphiceptin 
and $\beta$-casomorphins: Correlation with the morphine $(\mu)$ receptor binding affinity. Life Sciences 30, 1547-1551.

Chang KJ, Killian A, Hazum E \& Cuatrecasas P (1981) Morphiceptin: a potent and specific agonist for morphine $(\mu)$ receptors. Science 212, 75-77.

Chiba H, Tani F \& Yoshikawa M (1989) Opioid antagonist peptides derived from $\beta$-casein. Journal of Dairy Research 56, 363-366.

Chiba H \& Yoshikawa M (1986) Biologically functional peptides from food proteins: new opioid peptides from milk proteins. In Protein Tailoring for Food and Medical Uses, pp. 123-153 [RE Feeney and JR Whitaker, editors]. New York: Marcel Dekker.

Daniel H, Vohwinkel M \& Rehner G (1990a) Effect of casein and $\beta$-casomorphins on gastrointestinal motility in rats. Journal of Nutrition 120, 252-257.

Daniel H, Wessendorf A, Vohwinkel M \& Brantl V (1990b) Effect of $\mathrm{D}$-Ala ${ }^{2,4}, \mathrm{Tyr}^{5}-\beta$-casomorphin-5-amide on gastrointestinal functions. In $\beta$-Casomorphins and Related Peptides, pp. 95-104 [F Nyberg and V Brantl, editors]. Uppsala: FyrisTryck AB.

Elitsur Y \& Luk GD (1991) Beta-casomorphin (BCM) and human colonic lamina propria lymphocyte proliferation. Clinical and Experimental Immunology 85, 493-497.

Erll G, Hahn A, Brantl V \& Daniel H (1994) $\beta$-Casomorphins and intestinal net fluid transport in vivo. In $\beta$-Casomorphins and Related Peptides: Recent Developments, pp. 143-149 [V Brantl and $\mathrm{H}$ Teschemacher, editors]. Weinheim: VCH.

Fiat AM \& Jollès P (1989) Caseins of various origins and biologically active casein peptides and oligosaccharides: structural and physiological aspects. Molecular and Cellular Biochemistry 87, 5-30.

Hamel H, Kielwein G \& Teschemacher H (1985) $\beta$-casomorphin immunoreactive materials in cow's milk incubated with various bacterial species. Journal of Dairy Research 52, 139-148.

Höllt V (1983) Multiple endogenous opioid peptides. Trends in Neuroscience 6, 24-26.

Juillard V, Laan H, Kunji ERS, Jeronimus-Stratingh CM, Bruins AP \& Konings WN (1995) The extracellular PI-type proteinase of Lactococcus lactis hydrolyzes $\beta$-casein into more than one hundred different oligopeptides. Journal of Bacteriology 177, 3472-3478.

Loukas S, Panetsos F, Donga E \& Zioudrou C (1990) Selective $\delta$ antagonist peptides, analogs of a-casein exorphin, as probes for the opioid receptor. In $\beta$-Casomorphins and Related Peptides, pp. 65-75 [F Nyberg and V Brantl, editors]. Uppsala: FyrisTryck AB.

Loukas S, Varoucha D, Zioudrou C, Streaty RA \& Klee WA (1983) Opioid activities and structures of a-casein-dervied exorphins. Biochemistry 22, 4567-4573.

Mansfeld R, Kautni J, Grunert E, Brantl V \& Jöchle W (1990) Clinical application of bovine $\beta$-casomorphins for treatment of calf diarrhea. In $\beta$-Casomorphins and Related Peptides, pp. 105-108 [F Nyberg and V Brantl, editors]. Uppsala: FyrisTryck AB.

Matthies H, Stark H \& Hartrodt B (1984) Derivatives of $\beta$ casomorphins with high analgesic potency. Peptides 5, 463470.

Meisel H (1986) Chemical characterization and opioid activity of an exorphin isolated from in vivo digests of casein. FEBS Letters 196, 223-227.

Meisel H (1997a) Biochemical properties of regulatory peptides derived from milk proteins. Biopolymers (Peptide Science) 43, $119-128$.

Meisel H (1997b) Biochemical properties of bioactive peptides derived from milk proteins: potential nutraceuticals for food and pharmacological applications. Lifestock and Production Science 50, 125-138.
Meisel H \& Bockelmann W (1999) Bioactive peptides encrypted in milk proteins: proteolytic activation and tropho-functional properties. Antonie van Leeuwenhoek 76, 207-215.

Meisel H \& Schlimme E (1996) Bioactive peptides derived from milk proteins: ingredients for functional foods? Kieler Milchwirtschaftliche Forschungsberichte 48, 343-357.

Mentz P, Neubert K, Liebmann C, Hoffmann S, Schrader U \& Barth A (1990) Pharmacological effects of $\beta$-casomorphins on the cardiadic function. In $\beta$-Casomorphins and Related Peptides, pp. 133-139 [F Nyberg and V Brantl, editors]. Uppsala: Fyris-Tryck AB.

Mierke DF, Nößner G, Schiller PW \& Goodman M (1990) Morphiceptin analogs containing 2-aminocyclopentane carboxylic acid as a peptidomimetic for proline. International Journal of Peptide Research 35, 34-45.

Panksepp J, Normansell L, Siviy S, Rossi J \& Zolovick AJ (1984) Casomorphins reduce separation distress in chicks. Peptides $\mathbf{5}$, 829-831.

Paroli E (1988) Opioid peptides from food (the exorphins). World Reviews of Nutrition and Dietetics 55, 58-97.

Pihlanto-Leppälä A, Antila P, Mäntsälä P \& Hellman J (1994) Opioid peptides produced by in-vitro proteolysis of bovine caseins. International Dairy Journal 4, 291-301.

Rokka T, Syväoja E-L, Tuominen J \& Korhonen H (1997) Release of bioactive peptides by enzymatic proteolysis of Lactobacillus GG fermented UHT milk. Milchwissenschaft 52, 675-678.

Schusdziarra V, Schick R, de la Fuente A, Holland A, Brantl V \& Pfeiffer EF (1983a) Effect of $\beta$-casomorphins on somatostatin release in dogs. Endocrinology 112, 1948-1951.

Schusdziarra V, Schick R, de la Fuente A, Specht J, Klier M, Brantl V \& Pfeiffer EF (1983b) Effect of $\beta$-casomorphins and analogs on insulin release in dogs. Endocrinology 112, 885889.

Svedberg J, de Haas J, Leimenstoll G, Paul F \& Teschemacher H (1985) Demonstration of $\beta$-casomorphin immunoreactive materials in in vitro digests of bovine milk and in small intestine contents after bovine milk ingestion in adult humans. Peptides 6, 825-830.

Tani F, Shiota A, Chiba H \& Yoshikawa M (1994) Serorphin, an opioid peptide derived from bovine serum albumin. In $\beta$ Casomorphins and Related Peptides: Recent Developments, pp. 49-53 [V Brantl and H Teschemacher, editors]. Weinheim: $\mathrm{VCH}$.

Teschemacher H \& Koch G (1990) $\beta$-Casomorphins: possible physiological significance. In $\beta$-Casomorphins and Related Peptides, pp. 143-149 [F Nyberg and V Brantl, editors]. Uppsala: Fyris-Tryck AB.

Teschemacher H, Koch G \& Brantl V (1994) Milk protein derived atypical opioid peptides and related compounds with opioid antagonist activity. In $\beta$-Casomorphins and Related Peptides: Recent Developments, pp. 3-17 [V Brantl and H Teschemacher, editors]. Weinheim: VCH.

Teschemacher H, Koch G \& Brantl V (1997) Milk protein-derived opioid receptor ligands. Biopolymers (Peptide Science) 43, 99117.

Teschemacher H, Brantl V, Henschen A \& Lottspeich F (1990) $\beta$ Casomorphins - $\beta$-casein fragments with opioid activity: detection and structure. In $\beta$-Casomorphins and Related Peptides: Recent Developments, pp. 9-14 [V Brantl and $\mathrm{H}$ Teschemacher, editors]. Weinheim: VCH.

Teschemacher H, Umbach M, Hamel U, Praetorius K, AhnertHilger G, Brantl V, Lottspeich F \& Henschen A (1986) No evidence for the presence of $\beta$-casomorphins in human plasma after ingestion of cows' milk or milk products. Journal of Dairy Research 53, 135-138.

Tomé D, Dumontier AM, Hautefeuille M \& Desjeux JF (1987) Opiate activity and transepithelial passage of 
intact $\beta$-casomorphins in rabbit ileum. American Journal of Physiology 253, G737-G744.

Umbach M, Teschemacher H, Praetorius K, Hirschhäuser R \& Bostedt H (1985) Demonstration of a $\beta$-casomorphin immunoreactive material in the plasma of newborn calves after milk intake. Regulatory Peptides 12, 223-230.

Yen SSC, Quigley ME, Reid RL, Ropert JF \& Cetel NS (1985) Neuroendocrinology of opioid peptides and their role in the control of gonadotropin and prolactin secretion. American Journal of Obsterics and Gynecology 152, 485-493.

Yoshikawa M, Tani F \& Chiba H (1988) Structure-activity relationship of opioid antagonist peptides derived from milk proteins. In Peptide Chemistry, pp. 473-476 [T Shiba, editor]. Osaka: Protein Research Foundation.

Yoshikawa M, Tani F, Shiota H, Usui H, Kurahashi K \& Chiba H (1994) Casoxin D, an opioid antagonist/ileum-contracting/

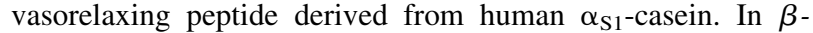
Casomorphins and Related Peptides: Recent Developments, pp. 43-48 [V Brantl and H Teschemacher, editors]. Weinheim: $\mathrm{VCH}$. 